CARTA AL EDITOR

\section{ENFERMEDAD DEL SUERO SECUNDARIA A SUERO ANTIOFÍDICO}

\section{SERUM ILLNESS SECONDARY TO ANTIOPHIDIC SERUM}

\author{
Edinson Dante Meregildo-Rodriguez [i] ,2,a, Gustavo Adolfo \\ Vásquez-Tirado (10) ${ }^{3, b}$, Martha Genara Asmat-Rubio (iD) \\ Universidad Señor de Sipán, Chiclayo, Perú. \\ Hospital Regional Lambayeque, Lambayeque, Perú. \\ Hospital Regional Docente de Trujillo, La Libertad, Perú. \\ Médico internista, maestro en Medicina; ${ }^{\mathrm{b}}$ médico internista e intensivista; \\ ' químico farmacéutico, especialista en Farmacia Clínica.
}

Sr. Editor: La enfermedad del suero ocurre tras inyectar suero o proteínas extrañas que desencadenan una respuesta de anticuerpos IgG contra proteínas heterólogas ${ }^{(1-5)}$. Tras una búsqueda en las principales bases de datos, encontramos solo un reporte de caso en Perú de ES secundaria a suero antiofídico ${ }^{(6)}$. Esta comunicación tiene como objetivo alertar a los profesionales de la salud de un evento adverso y raro del suero antiofídico, como la enfermedad del suero y discutir criterios clínicos para el diagnóstico de ES secundaria a suero antiofídico (ESSA).

El caso corresponde a un varón de 68 años, procedente del caserío de Callanca, distrito de Monsefú, provincia de Chiclayo, sin antecedentes de relevancia. Ingresa al servicio de Emergencia del Hospital Regional Lambayeque, el 27 de junio de 2018, tras sufrir la mordedura, en la mano izquier$\mathrm{da}$, de una serpiente que él identifica como «macanche» (Bothrops barnetti). Se le administraron dos viales de suero antibotrópico polivalente $40 \mathrm{mg} / 10 \mathrm{~mL}$ (Instituto Nacional de Salud), y al día siguiente fue dado de alta con evolución favorable. El 5 de julio de 2018, el paciente inicia con cefalea, malestar, fiebre, artromialgias, rash morbiliforme pruriginoso asociado a habones y ampollas con contenido serohemático y edema con fóvea, por lo que cinco días después reingresa a emergencia (Figura 1). El paciente negó el uso de alguna otra sustancia antes de su reingreso. El paciente recibió clorfenamina $10 \mathrm{mg}$ y dexametasona $4 \mathrm{mg}$, vía intravenosa, cada seis horas, presentó mejoría clínica y fue dado de alta una semana después. La biopsia cutánea mostró hallazgos histopatológicos sugestivos de vasculitis leucocitoclástica.

Citar como: Meregildo-Rodriguez ED, Vásquez-Tirado GA, Asmat-Rubio MG. Enfermedad del suero secundaria a suero antiofídico. Rev Peru Med Exp Salud Publica. 2020;37(1):176-7. Doi: https://doi.org/10.17843/rpmesp.2020.371.4883

Correspondencia: Edinson Dante Meregildo Rodriguez; dante_meregildo@ hotmail.com

Recibido: 13/10/2019 Aprobado: 15/01/2020 En línea: 19/03/2020
Las características clínicas cardinales de la ES son dermatitis rash, fiebre, poliartralgias/poliartritis, y malestar general; que se inician una a dos semanas después de la primera exposición al agente responsable. La ES es causada por inmunización del huésped humano por proteínas heterólogas no humanas. La reacción requiere la presencia de antígenos, anticuerpos contra estos antígenos y la formación subsecuente de inmunocomplejos antígeno-anticuerpo ${ }^{(1-6)}$.

Entre el 5,6\% al 29\% de pacientes desarrollan ES tras administración de suero antiofídico ${ }^{(4,5)}$. Se ha descrito también el desarrollo de ES con otros tipos de sustancias como sueros antiarácnidos, antitoxinas microbianas (contra difteria, rabia, botulismo), anticuerpos monoclonales e inmunomoduladores (infliximab, rituximab, globulina antitimocítica, etc.), proteínas fibrinolíticas (estreptocinasa), entre otras ${ }^{(1-5)}$.

Virtualmente todos los pacientes con ES tienen fiebre $\left(>38,5^{\circ} \mathrm{C}\right)$, pero los escalofríos son inusuales. Las manifestaciones cutáneas de la ES son variables. Casi todos tienen rash pruriginoso, que suele ser la manifestación clínica más precoz. El rash suele ser urticarial, maculopapular, vasculítico (púrpura palpable), erupciones morbiliformes, pápulas o maculopápulas ${ }^{(1-6)}$, tal como se muestra en la Figura 1 (fotografías tomadas con autorización del paciente). Las mucosas no se ven afectadas, lo cual es un dato clínico útil para distinguir la ES de cuadros clínicos similares como el Síndrome de Stevens-Johnson y la necrólisis epidérmica tóxica. El rash, frecuentemente, surge alrededor del sitio de la inyección, pero puede aparecer en otros lugares (tronco, ingle, abdomen, etc.) ${ }^{(1-5)}$. La mayoría de estas características se presentaron en el paciente y, con menor frecuencia, se puede encontrar edema, linfadenopatías, cefalea, visión borrosa, esplenomegalia, uveítis anterior, neuropatía periférica, nefropatía, y vasculitis sistémica ${ }^{(1-5)}$.

El diagnóstico de la ES usualmente es clínico, basado en el patrón característico de inicio agudo o subagudo de las manifestaciones clínicas cardinales, que se presenta una o dos semanas después de la exposición al agente causal. No existe un consenso respecto a los criterios requeridos para el diagnóstico de la ESSA ${ }^{(1-6)}$. Una definición práctica y que podría aplicarse en el país es el propuesto por Ryan y col. ${ }^{(4)}$, que define ESSA por la presencia de tres o más de los siguientes criterios: fiebre, rash eritematoso/urticarial, mialgias/artralgias, cefalea, malestar, náuseas/vómitos, que se presentan cinco a 20 días después de la administración del antiveneno ${ }^{(4)}$. Ninguna de las series publicadas recientemente incluye la biopsia cutánea como criterio de ES ${ }^{(1-5)}$.

La biopsia cutánea no es útil para confirmar el diagnóstico, dado que los hallazgos histopatológicos son variables e inespecíficos. En el presente reporte, dado el antecedente de exposición a suero heterólogo, y la presentación clínica muy característica, el diagnóstico no representó dificultad.

El pronóstico de la ES fue bueno, ya que se autolimita en una o dos semanas después de la suspensión del agente causal ${ }^{(1,2)}$. En conclusión, la ESSA es una reacción de hipersensibilidad rara, 


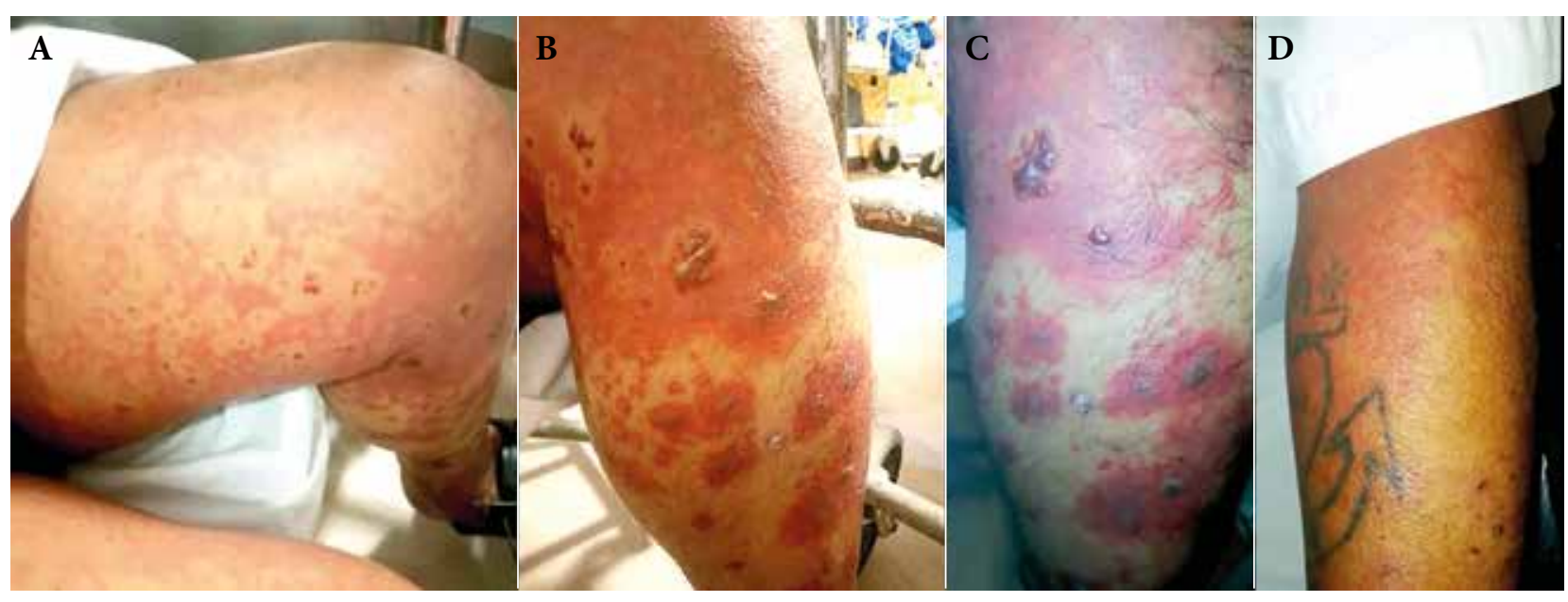

Figura 1. Imágenes del ingreso del paciente a emergencia. Se observa rash eritematoso pruriginoso generalizado con predominio de extremidades (A a D), asociado a lesiones papulares, placas sobreelevadas además vesículas y flictenas con contenido serohemático (B, C), edema blando con fóvea.

cuyo diagnóstico es eminentemente clínico, por lo que la biopsia cutánea deberá realizarse sólo en caso de duda diagnóstica.

Contribuciones de los autores: EDMR y GAVT contribuyeron en la concepción, redacción, revisión y aprobación final del manuscrito.

\section{REFERENCIAS BIBLIOGRÁFICAS}

1. Wener MH, Adkinson Jr. NF. Serum sickness and serum sickness-like reactions. Feldweg AM, ed. UpToDate. Waltham, MA: UpToDate Inc. Retrieved from http://www.uptodate.com Last accessed Oct 10, 2019.

2. de Silva HA, Ryan NM, de Silva HJ. Adverse reactions to snake antivenom, and their prevention and treatment. Br J Clin Pharmacol. 2016; 81(3):446-452. doi:10.1111/bcp.12739

3. Ryan NM, Downes MA, Isbister GK. Clinical features of serum sickness after Australian snake antivenom. Toxicon. 2015; 108:181-3. doi: 10.1016/j. toxicon.2015.10.012.
MGAR se encargó del reporte y seguimiento del paciente, y la revisión y aprobación final del manuscrito.

Fuentes de financiamiento: Autofinanciado.

Conflictos de interés: Los autores reportan no tener conflictos de interés.

4. Ryan NM, Kearney RT, Brown SG, Isbister GK. Incidence of serum sickness after the administration of Australian snake antivenom (ASP-22). Clin Toxicol (Phila). 2016; 54(1):27-33. doi: 10.3109/15563650.2015.1101771.

5. Mong R, Ng VCH, Tse ML. Safety profile of snake antivenom (use) in Hong Kong - a review of 191 cases from 2008 to 2015. Clin Toxicol (Phila). 2017; 55(10):1066-1071. doi: 10.1080/15563650.2017.1334916.

6. Paucar K, Del Solar M, Bravo F, Salomón M, Puell M, Feria K, Ramos C, Giglio P. Enfermedad del suero. Folia Dermatol Peru. 2011; 22 (2): $91-94$ 